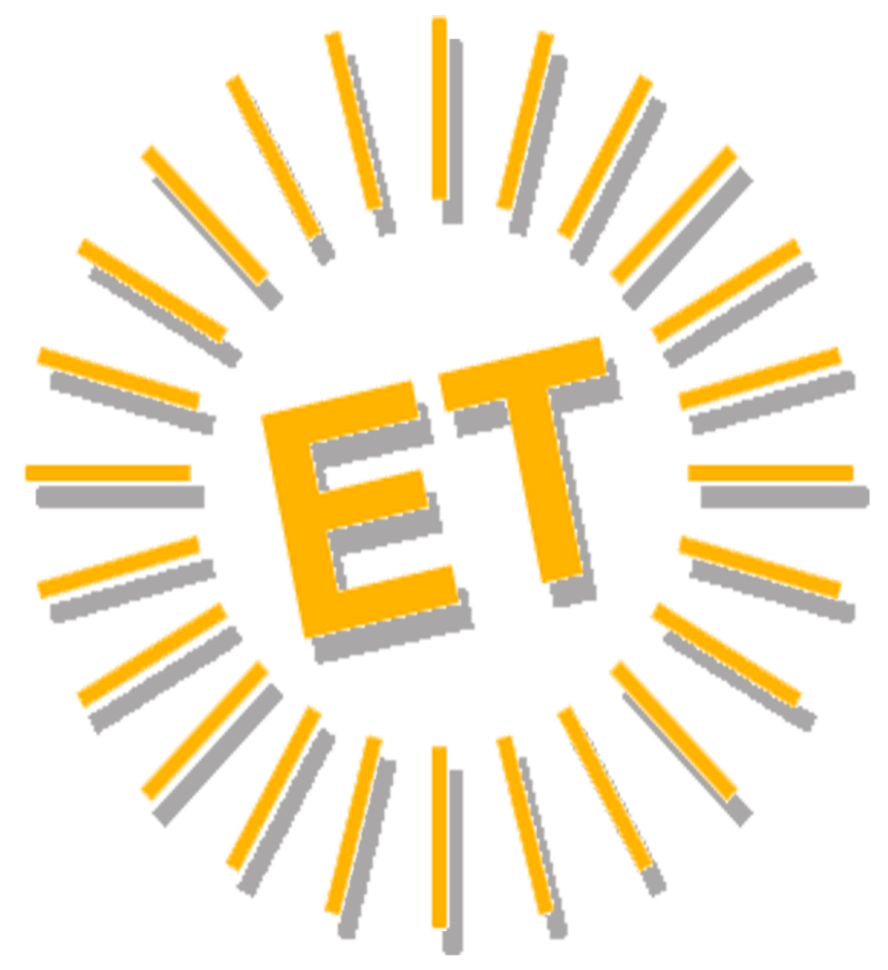




\section{Editorial Team}

\section{Editor in Chief}

Alfonso Vargas-Sánchez, University of Huelva, Spain

\section{Associate Editor}

Mirko Perano, Reald University College, Albania

\section{Books Review Editor}

Brendan Paddison, York St. John University, United Kingdom

\section{Secretariat}

Elena García de Soto, University of Huelva, Spain

Cinta Borrero-Domínguez, University of Huelva, Spain

\section{Style reviewer and text editor}

Anestis Fotiadis, I-SHOU University, Taiwan, Province of China

\section{Editorial Board}

José Manuel Alcaraz, Murdoch University, Australia Mario Castellanos-Verdugo, University of Seville, Spain José Antonio Fraiz-Brea, University of Vigo, Spain José Manuel Hernández-Mogollón, University of Extremadura, Spain

Tzung-Chen Huan, National Chiayi University, Taiwan, Province of China

Shaul Krakover, Ben Gurion University, Israel Jean Pierre Levy-Mangin, University of Quebec, Canada Tomás López-Guzmán, University of Córdoba, Spain Yasuo Ohe, Chiba University, Japón María de los Ángeles Plaza-Mejía, University of Huelva, Spain Nuria Porras-Bueno, University of Huelva, Spain João Albino Silva, Algarve University, Portugal

\section{Advisory Board (Spanish Members)}

Juan Manuel Berbel-Pineda, Pablo de Olavide University, Spain César Camisón-Zornoza, Uniersity of Valencia, Spain Enrique Claver-Cortés, University of Alicante, Spain María Teresa Fernández-Alles, University of Cádiz, Spain José Luis Galán-González, University of Seville, Spain Félix Grande-Torraleja, University of Jaén, Spain

Antonio Leal-Millán, University of Seville, Spain Inmaculada Martín-Rojo, University of Málaga, Spain Antonio Manuel Martínez-López, University of Huelva, Spain Francisco José Martínez-López, University of Huelva, Spain Pablo A. Muñoz-Gallego, University of Salamanca, Spain
Francisco Riquel-Ligero, University of Huelva, Spain José Miguel Rodríguez-Antón, Autonomous University of Madrid, Spain

Sandra Sanchez-Cañizares, University of Cordoba, Spain Josep Francesc Valls-Giménez, ESADE, Spain

\section{Advisory Board (Other European Members)}

Tindara Abbate, University of Messina, Italy Paulo Aguas, University of Algarve, Portugal Carlos Costa, Aveiro University, Portugal Dianne Dredge, Aalborg University, Denmark Salvatore Esposito de Falco, University of Rome "La Sapienza", Italy

Sheila Flanagan, Dublín Institute of Technology, Ireland Tania Gorcheva, Tsenov Academy of Economics, Bulgaria Tadeja Jere Jakulin, University of Primorska, Slovenia Metin Kozak, Mugla University, Turkey Álvaro Matias, Lusiada University, Portugal Alfonso Morvillo, National Research Council, Italy Alexandru Nedelea, Stefan cel Mare University of Suceava, Romania

Claudio Nigro, University of Foggia, Italy

Angelo Presenza, University "G. D'Annunzio" of Chieti-Pescara, Italy

Kanes Rajah, Royal Agricultural University, United Kingdom

\section{Advisory Board (Members from the rest of the world)}

John Allee, American University of Sharjah, United Arab Emirates

Nestor Pedro Braidot, National University of La Plata, Argentina

Roberto Elias Canese, Columbia University, Rector, Paraguay

Luca Casali, Queensland University of Technology, Australia Nimit Chowdhary, Indian Institute of Tourism and Travel Management, India

Steven Chung-chi Wu, National Pingtung University of Science and Technology, Taiwán

Dianne Dredge, Southern Cross University, Australia Daniel Fesenmaier, Temple University, United States

Babu George, Alaska Pacific University, United States Dogan Gursoy, Washington State University, United States Jafar Jafari, University of Wisconsin-Stout, United States Sanggun Lee, Pai Chai University, Korea Republic of Albert Yeh Shangpao, I-SHOU University, Taiwán Pauline Sheldon, University of Hawaii, United States Germán A. Sierra-Anaya, University of Cartagena de Indias, Rector, Colombia Xiaohua Yang, University of San Francisco, United States 


\title{
RELIGIOUS TOURISM: AN ANALYSIS OF ANTECEDENTS OF THE INTENTION TO PARTICIPATE IN RELIGIOUS FESTIVALS
}

\author{
Kelisha Govender \\ University of the Witwatersrand (South Africa) \\ kelisha.govender@students.wits.ac.za
}

Norman Chiliya

University of the Witwatersrand (South Africa)

norman.chiliya@wits.ac.za

Tinashe Chuchu

University of Pretoria (South Africa)

tinashe.chuchu@up.ac.za

Eugine Tafadzwa Maziriri

University of the Free State (South Africa)

MaziririET@ufs.ac.za

Tinashe Ndoro

University of Pretoria (South Africa)

tinashe.ndoro@up.ac.za 


\section{ABSTRACT}

Religious tourism relates to tourism which is motivated by faith or religious beliefs. Religious tourism has resulted in individuals moving from one place to the other for purposes of partaking in religious festival celebrations. The purpose of the present study was therefore to investigate antecedents of intention to engage in religious festivals. To provide context to the research, two religious festivals were the focus of the study namely, Holi and Christmas. Non-probability sampling, a form of convenience sampling, was adopted in selecting participants. Data was obtained from 224 participants who reside in Johannesburg, South Africa. Data collection involved the administration of a survey questionnaire. The antecedents of the intention to participate in religious festivals included attitudes and subjective norms. The findings from the study suggested that attitudes had the most significant impact towards intention to engage in religious festivals. Suggestions for future research and implications of the research are discussed.

\section{KEYWORDS}

Religion, Tourism, Festivals, Intention.

ECONLIT KEYS

M10; M30; M31; L83

\section{INTRODUCTION AND BACKGROUND}

Religion is one of the factors that motivates people to set out on journeys and engage in great pilgrimages to different parts of the world (Cristea, Apostol \& Dosescu, 2015). Hence, religious tourism involves visiting destinations solely or largely motivated by religious purposes and is one of the oldest types of tourism (Rinschede, 1992). In the not so distant past, tourism had become a topic of interest due to local and economic development it provides. Religion in tourism in no exception (Amorim, Jiménez-Caballero \& Almeida, 2019; Jiménez \& Martín, 2004). Modern tourism has become the functional and symbolic equivalent of an increasing number of traditional religious activities, such as festivals and pilgrimages (Sharpley \& Sundaram, 2005). Leone (2011) argued that Christmas is arguably the most widely celebrated religious holiday and has become one of the most profitable times of the year for retail stores. Although there has been much debate as to when the birth of Jesus Christ actually occurred, the 25th of December is the day that is globally celebrated by Christians as the day of his birth (Leone, 2011). The Christmas season has become an excuse for businesses to use marketing tactics, such as sales and discounts, to exploit the significant traditions of gift giving and hosting Christmas 
lunches which persuade customers to spend significant amounts of money in stores and malls (Leone, 2011).

Just like Christmas is scared to Christians, one of the most festive days in the Hindu calendar is Holi. Holi is primarily celebrated in North India and in some parts of South India and falls on the full moon day of Phalguna which can occur between the months of February and March. During Holi, worshipers can be found in massive religious gatherings, where they pray, visit holy places and bath in sacred waters. Against the aforementioned background, it is imperative to note that religious travels still represent an important market segment in the tourism and travel industry. For spreading the social and economic benefits that religious tourism offers, authorities of the religious destinations need to understand the behavioural patterns of tourists (Albayrak, Herstein, Caber, Drori, Bideci \& Berger 2018). Many researchers admit that every market understanding starts with identifying tourist motivations and the antecedents driving their behaviour (van Vuuren \& Slabbert, 2011; Weaver, McCleary, Han, \& Blosser 2009). Interestingly, despite the global importance and popularity of religious tourism, few researchers investigate the experiences of religious tourists (Albayrak, Herstein, Caber, Drori, Bideci \& Berger, 2018). Hence, the religious tourism literature needs to be expanded through additional studies that would provide a deeper understanding of the phenomenon. The review of literature indicates that scholars generally focus on the exploration and comparison of different types of travellers' experiences, such as tourists and pilgrims (Bond, Packer, \& Ballantyne 2015; Nyaupane, Timothy, \& Poudel, 2015). In addition, the results of many studies showed that individuals who engage in different religious celebrations have different behaviour patterns (Bailey \& Sood, 1993; Essoo \& Dibb 2004). However, Albayrak, et al. (2018) emphasised that, to date, behavioural patterns of individuals who engage in religious celebrations have not been fully examined. Apart from the impact of religious tourists on the economy, it is important to note that the aim of this paper is to provide a more informed and empirically based image on the antecedents that influence individuals to participate in religious festivals: Arising from the aforementioned objective, the following research questions are raised to guide the study:

- Does behavioural belief positively and significantly impact attitudes towards participating in religious festivals? 
- To what extent does normative belief and motivation to comply positively and significantly impact subjective norms?

- Can attitudes and subjective norms positively and significantly impact the intention to participate in religious festivals?

Inferring from the research questions formulated in the preceding section, it is vital to mention that this study contributes to filling the gap in literature pertaining to the behavioural patterns of individuals towards partaking in religious celebrations. In this vein, the relationship between perceived behavioural control, normative belief, motivation to comply, attitudes and subjective norms with the intention to participate in religious festivals is investigated. The study also contributes to the body of knowledge by providing a quantitative study on the subject matter, the results of which will be helpful to policymakers who are not aware of the importance of religious tourism in relation to a country's economy. Furthermore, the findings of the study will be used to create better religious tourism policies. Moreover, this study will assist other scholars and researchers in further developing the religious tourism research field.

The paper has been organised such that the next section provides the problem statement and research gap of the study, and this is followed by the research context, empirical literature, thus prompting research hypotheses development. Thereafter, the section on research design and methodology follows. Finally, there is a presentation of the findings, discussion and conclusion.

\section{2) PROBLEM STATEMENT AND RESEARCH GAP}

The research aims to fill the gap in literature which relates to understanding the antecedents of the participation in religious celebrations. The study positively contributes towards understanding the relationship between perceived behavioural control, normative belief, motivation to comply, attitudes, subjective norms and intention to participate in religious festivals. From the literature, it can be noted that there are deficiencies in studies that provide an understanding of the antecedents that influence the individual's intention to participate in religious festivals. Remarkably, most international studies have been conducted in countries such as Bhutan, Malaysia, Taiwan, Norway and the Philippines, among others. For example, 
Suntikul and Dorji (2016) determined local perspectives on the impact of tourism on religious festivals in Bhutan. In addition, bin Haji Ishak (2010) examined the cultural and religious festivals in Malaysia. Furthermore, Lee, Fu and Chang (2015) examined the relationships among emotional experience, authenticity experience, festival identity, and support for tourism development among attendees at two wellknown traditional religious festivals in Taiwan. Krogstad (2017) examined religious festivals in early childhood education and care (ECEC) institutions in Norway. Moreover, Adiova (2014) conducted a study which focused on music, dance, and negotiations of identity in the religious festivals of Bicol, Philippines.

Even within the South African context, several research studies have focused on religious tourism in various contexts by focusing on the perceptions of religious tourism in South Africa (Nyikana 2017; Apleni, Vallabh \& Henama 2017); challenges and opportunities in religious tourism (Henama \& Sifolo 2018) and exploring the prospects of establishing a nexus between religious tourism and local economic development (Paul, 2018). Therefore, deducing from the aforementioned studies, it is imperative to note that there seems to be a scarcity of studies that have determined the antecedents that influence an individual's willingness to participate in religious festivals. Therefore, the fundamental motivation behind this investigation is to fill this gap. In addition, this study sought to use structural equation modelling to ascertain the causal relationships of the variables under investigation (perceived behavioural control, normative belief, motivation to comply, attitudes, subjective norms and intention to participate in religious festivals). It would be naïve to assume a priori that findings from developed countries in Europe, or even from the newly developed countries in Asia, apply in Africa. Perhaps, research which examines the antecedents of the intention to participate in religious festivals in the African context might yield different results from other parts of the world. Thus, in order to confirm or disconfirm the findings of previous studies, this kind of research related to religious festivals in Africa is evidently long overdue. Hence, what this current investigation examines, by means of a proposed conceptual model, is the effect of perceived behavioural control, normative belief and motivation to comply has on attitudes and subjective norms. It also seeks to determine how attitudes and subject norms have an impact on the intention to participate in religious festivals.

\section{3) RESEARCH CONTEXT AND SETTING}


The religions specifically looked at for purposes of the research were Christianity and Hinduism. Hence, empirical data was gathered from individuals who participate in Christmas and Holi festivals.

\section{4) THEORETICAL UNDERPINNING}

The theoretical grounding for the study was based on two theories, namely, the theory of planned behaviour and the theory of reasoned action. These theories were selected for the study because of their predictive power of human behaviour. The object of the present study was to investigate the antecedents of individuals' intention to participate in religious festivals.

\section{REVIEW OF LITERATURE AND DEVELOPMENT OF HYPOTHESES}

\section{1) PARTICIPATION IN RELIGIOUS TOURISM}

Religious tourism refers to tourism that is motivated by faith or religious beliefs (Sharpley \& Sundaram, 2005). Tourism scholars observed that individuals who visit sacred destinations and dwellings for various religious reasons are deemed as religious tourists (Collins-Kreiner, 2010; Ron, 2009; Terzidou, Scarles \& Saunders, 2018). According to Timothy and Olsen (2006), travel is not a new phenomenon and religion has been synonymous with journeys for centuries, thus religion is considered the earliest form of non-economic travel (Jackowski \& Smith, 1992). Participation in religious festivals or visiting religious sites is associated with motives related to constructive powers (i.e. religious authorities and beliefs). Religion creates collective realities that involve various expectations for the individuals who belong to the religion. Through collective understanding and mutual observations, motivations are created, based on particular values and behaviours that are acquired through processes of imitation, repetition and role-play that enable individuals to be part of the whole (Belhassen et al., 2008).

\section{2) ATTITUDES}


Attitudes can be defined as the general evaluation of a person performing a specific behaviour (Gumpo, Chuchu, Maziriri \& Madinga, 2020). An attitude is the enduring favourable or unfavourable assessments, emotions and tendencies of action towards a certain behaviour of a person (Roberts-Lombard \& Parumasur, 2017). If the attitude towards behaviour is positive, the individual's desire to perform that particular behaviour increases (Ajzen, 1991). Attitudes can be described as a person's overall assessment of performing a particular behaviour (Celik \& Yilmaz, 2011). Individuals are noted as being able to perform behaviour over which they have control. Deducing from the aforementioned explanations, it can be noted that an individual is more likely to perform specific behaviour if he or she perceives that they have control over that behaviour. Hence, the following hypothesis can be deduced in the study:

$>\mathbf{H}_{1}$ : behavioural belief has an impact on attitudes towards participating in religious festivals.

\section{3) BEHAVIOURAL BELIEF}

Behavioural belief relates to the beliefs individuals hold about a behaviour and its consequences. These beliefs are formed in a rational and unbiased manner which thereby informs reality. Beliefs are a reflection that individuals have of the information individuals possess in relation to the behaviour. Behavioural beliefs are related to the expectations that individuals hold that performing a behaviour will result in experiencing pleasure, pain, fear, regret or other emotions (Ajzen, 2011). This study looks at perceived behavioural control in the context of an individual believing that they can carry out the task of partaking in a religious festival.

\section{4) NORMATIVE BELIEFS}

Normative beliefs can be considered a form of knowledge structure, referred to as a database or script by Hilvert-Bruce and Neill (2020). These knowledge structures are sculpted by past experiences, and thus can be weakened or strengthened according to experience (Hilvert-Bruce \& Neill, 2020). Normative beliefs are thereby influenced by beliefs about the expectations of relevant others and the extent to which the individual is motivated to conform to these expectations 
(Ajzen 1991). Normative beliefs are further reliant on interpersonal influences (e.g. word-of-mouth information from family, friends and colleagues or peers for an individual to perform the behaviour) and external influence (e.g. mass media reports, government promotions and other non-personal information affecting whether the individual performs the behaviour) (Lin 2010).

\section{5) MOTIVATION TO COMPLY}

Strydom (2018) elucidates that people's intentions depend on their motivation to comply with what they believe is a desired action, what they feel is expected of them and "what they think they are supposed to do". In addition, Aghenta (2014) is of the view that motivation to comply has to do with the degree to which the individual feels compelled to conform to what their significant others expect. When an individual thinks that significant others approve behaviours that individual feels it is important to act in line with the beliefs of others, a positive subjective norm develops (Aghenta 2014).

\section{6) SUBJECTIVE NORMS}

According to Wan, Shen and Choi (2018), subjective Norm (SN) is an individual's perceived influence by other individuals or groups that are important or close to him/her (like friends, peers, neighbours). Subjective norm is defined as the perceived social pressure to perform or not to perform the behaviour in question (Konietzny, Caruana, \& Cassar, 2018). The theory of planned behaviour views influence or pressure from friends and social groups to be important when one is highly motivated to comply with the exerted pressure (Zoonen, Verhoeven \& Elvin, 2014). The effect of SN on behavioural intention has been supported by some previous studies. Zhou (2011) concluded that SN impacts on online community users' participation intention, and Akman (2014) concluded that SN has an effect on behavioural intention. Furthermore, it can be argued that normative belief and motivation to comply influence subjective norms. In this vein, the following hypotheses can be deduced in the study:

$>\mathbf{H}_{2}$ : normative beliefs have an impact on subjective norms.

$>\mathbf{H}_{3}$ : motivation to comply has an impact on subjective norms. 


\section{7) INTENTION TO PARTICIPATE IN A RELIGIOUS FESTIVAL}

Intention is a function of its three direct determinants of attitude towards behaviour, subjective norm and perceived behavioural control (PBC) (Maziriri, Mapuranga, \& Madinga, 2019; Mhlophe, 2015). This construct represents an individual's motivation to conduct a specific behaviour (Maziriri, Mapuranga, \& Madinga, 2019). Fishbein and Ajzen (1975) explained that the construct of intention is based on the individual's attitude, assessment and external factors. Intention refers to decision-making that suggests a reason to participate in a specific act (Mirabi, Akbariyeh, \& Tahmasebifard 2015). According to Ajzen (1991), intention is a predictor of actual behaviour, based on the understanding that the formation of an intention results from a combination of attitudes towards the behaviour, subjective norms and perceived behavioural control. Deducing from the aforementioned elucidations and for the purpose of this study, the researchers seek to determine tourists' intention to participate in a religious festival. Hence, the following hypotheses for the study are proposed:

$>\mathbf{H}_{4}$ : attitudes have an impact on the intention to participate in religious festivals.

$>\mathbf{H}_{5}$ : subjective norms have an impact on the intention to participate in religious festivals.

\section{CONCEPTUAL MODEL}

The conceptual model was based on the theory of planned behaviour which was adapted to the context of participation in religious festivals. The antecedents on the intention to participate in religious festivals are attitudes and subjective norms. However, attitudes are directly influenced by perceived behavioural control, while normative belief and motivation to comply directly influence subjective norms. Therefore, based on the aforementioned literature, the following hypotheses were proposed and a conceptualised model based on the theory of planned behaviour was developed. 


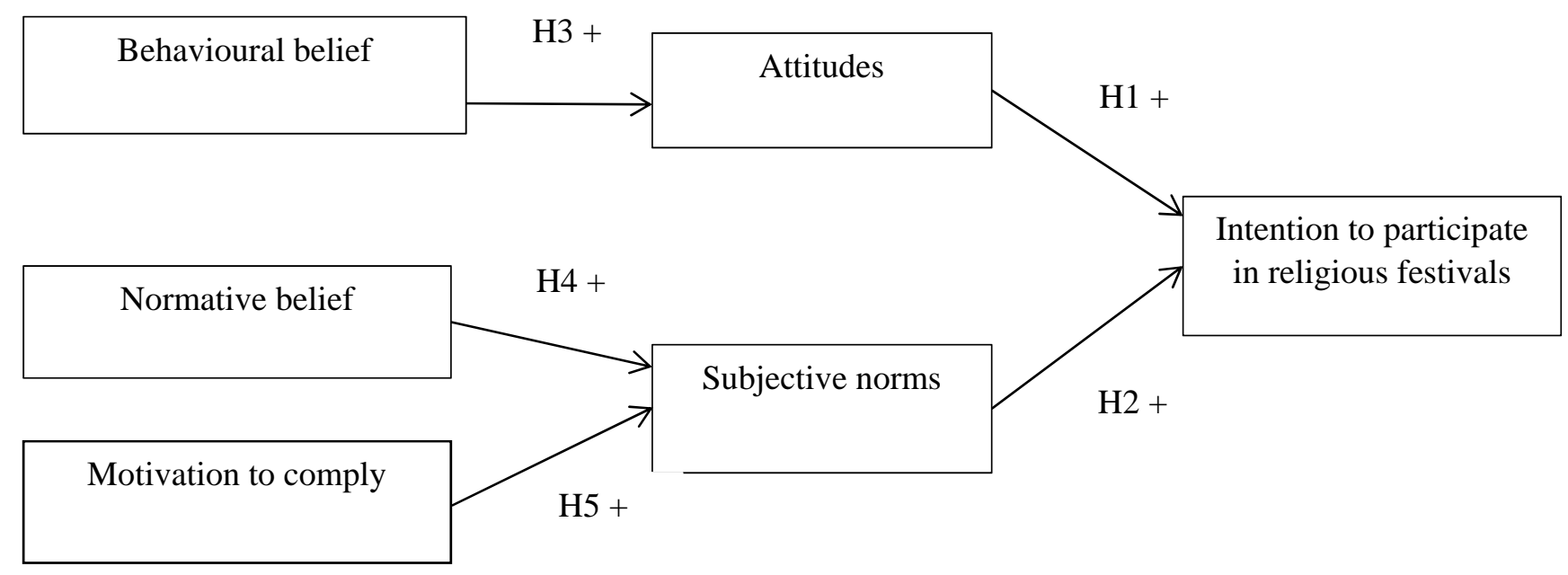

Fig.1: Modified: Theory of Planned Behaviour Framework Source: Authors' own work

The following section presents the study's research methodology. This is then followed by the results, implications and suggestions for future research.

\section{METHODOLOGY AND DESIGN}

The research adopted a quantitative research approach which utilised the positivist paradigm. This was imperative in order to obtain objective findings. Due to the nature and sensitivity of the study (focusing of people's religious habits in relation to festivals), research ethics were taken into consideration where participation was voluntary. Furthermore, anonymity and confidentiality was guaranteed. The sampling, data collection and analysis are therefore explored in this section.

\section{1) SAMPLING}

The target population was individuals residing in Johannesburg, South Africa, who identified as participants in religious festivals. Since it was not possible to obtain a sampling frame for such a population, convenience sampling, a form of nonprobability sampling, was used to select respondents for the survey. In order to qualify for participation in the study, respondents had to be at least 18 years of age or older.

\section{2) DATA COLLECTION}


In terms of gathering data, a self-administered survey was distributed in Johannesburg where 224 respondents provided answers to the survey. The questionnaire was therefore based on participation in religious festivals guided by the theory of planned behaviour (Ajzen 1991). The data collection instrument was composed of two sections (see table 1), the first being demographic characteristics of the sample that include age, gender, educational level and religious beliefs. The second part of the data collection instrument comprised 5-point Likert-scale questions that include; five items on behavioural beliefs, six items on normative beliefs, four items on motivation to comply, six items on attitudes, five items on subjective norms and six items on intention to participate in religious festivals. This section had a total of 32 questions while the entire survey was made up of 36 questions (see table 1).

\section{3) DATA ANALYSIS}

After data collection, the data was processed through the Statistical Package for the Social Sciences (SPSS) 24, for computing descriptive statistics that illustrate the sample profile features such as gender, age, educational level and religious beliefs of the participants. Additional analysis was done with the Analysis of the Moment Structures (AMOS) 24. This was to conduct structural equation modelling of the proposed hypotheses of the conceptual framework. The results from data analysis are presented in the following section and illustrated in table 1 below.

\section{RESEARCH FINDINGS}

\section{1) DESCRIPTIVE STATISTICS}

Table 1 below depicts the participant's profile. 


\begin{tabular}{|l|c|c|}
\hline GENDER & FREQUENCY & PERCENTAGE \\
\hline Male & 83 & $37.1 \%$ \\
\hline Female & 141 & $62.9 \%$ \\
\hline AGE & & \\
\hline $18-24$ & 115 & $51.3 \%$ \\
\hline $25-34$ & 72 & $32.1 \%$ \\
\hline $35-44$ & 18 & $8.0 \%$ \\
\hline $45-54$ & 15 & $6.7 \%$ \\
\hline $55-64$ & 4 & $1.8 \%$ \\
\hline EDUCATION & & $13.4 \%$ \\
\hline Diploma & 30 & $51.3 \%$ \\
\hline Undergraduate & 115 & $12.5 \%$ \\
\hline Postgraduate & 28 & $22.8 \%$ \\
\hline Other & 51 & \\
\hline RELIGION & & $40.2 \%$ \\
\hline Christian & 90 & $17.4 \%$ \\
\hline Hindu & 39 & $42.4 \%$ \\
\hline Other & 95 & \\
\hline
\end{tabular}

Table 1: Sample profile

Source: Authors' own work

The table above presents the description of the participants. The participants were asked to report their demographic information on gender, age, education level and religion. The respondents were predominantly females $(62.9 \%)$ and the majority of the respondents were between the age group 18-24 (51.35\%). Individuals with the education level of undergraduates made up the largest group (51.3\%), and finally, in the category of religion, Christians were the majority group (40.2\%). The accuracy analysis statistics are presented in the following table (table 2).

\begin{tabular}{|c|c|c|c|c|c|c|c|c|c|}
\hline \multirow{2}{*}{$\begin{array}{l}\text { Research } \\
\text { Construct }\end{array}$} & \multicolumn{9}{|c|}{ Descriptive Statistics } \\
\hline & \multicolumn{3}{|c|}{ Mean Value } & \multicolumn{2}{|c|}{$\begin{array}{l}\text { Standard } \\
\text { Deviation }\end{array}$} & $\begin{array}{l}\text { Alpha } \\
\text { value }\end{array}$ & C.R. & AVE & $\begin{array}{l}\text { Factor } \\
\text { Loading }\end{array}$ \\
\hline \multirow{6}{*}{ Intention } & INT1 & 5.310 & \multirow{6}{*}{4.563} & 1.964 & \multirow{6}{*}{2.050} & \multirow{6}{*}{0.831} & \multirow{6}{*}{0.780} & \multirow{6}{*}{0.442} & 0.938 \\
\hline & INT2 & 4.970 & & 2.105 & & & & & 0.935 \\
\hline & INT3 & 5.320 & & 1.949 & & & & & 0.848 \\
\hline & INT4 & 3.880 & & 2.114 & & & & & 0.248 \\
\hline & INT5 & 3.610 & & 2.024 & & & & & 0.238 \\
\hline & INT6 & 4.290 & & 2.145 & & & & & 0.243 \\
\hline \multirow{2}{*}{ Attitude } & A1 & 6.130 & \multirow{2}{*}{5.730} & 1.358 & \multirow[b]{2}{*}{1.422} & & \multirow[b]{2}{*}{0.796} & \multirow[b]{2}{*}{0.415} & 0.870 \\
\hline & $\mathrm{A} 2$ & 5.790 & & 1.570 & & & & & 0.813 \\
\hline
\end{tabular}




\begin{tabular}{|c|c|c|c|c|c|c|c|c|c|}
\hline & A3 & 6.140 & & 1.294 & & \multirow{4}{*}{0.829} & & & 0.694 \\
\hline & A4 & 5.450 & & 1.381 & & & & & 0.442 \\
\hline & A5 & 5.290 & & 1.476 & & & & & 0.477 \\
\hline & A6 & 5.580 & & 1.455 & & & & & 0.406 \\
\hline \multirow{5}{*}{ Subjective norm } & SN1 & 5.500 & \multirow{5}{*}{5.160} & 2.013 & \multirow{5}{*}{2.007} & \multirow{5}{*}{0.821} & \multirow{5}{*}{0.929} & \multirow{5}{*}{0.604} & 0.753 \\
\hline & SN2 & 5.230 & & 1.848 & & & & & 0.772 \\
\hline & SN3 & 5.120 & & 2.213 & & & & & 0.830 \\
\hline & SN4 & 4.870 & & 1.900 & & & & & 0.743 \\
\hline & SN5 & 5.080 & & 2.060 & & & & & 0.784 \\
\hline \multirow{5}{*}{ Behavioural belief } & BB1 & 5.300 & \multirow{5}{*}{3.946} & 1.949 & \multirow{5}{*}{2.055} & \multirow{5}{*}{0.706} & \multirow{5}{*}{0.717} & \multirow{5}{*}{0.314} & 0.472 \\
\hline & BB2 & 3.130 & & 2.161 & & & & & 0.606 \\
\hline & BB3 & 3.510 & & 2.203 & & & & & 0.670 \\
\hline & BB4 & 3.820 & & 1.985 & & & & & 0.656 \\
\hline & BB5 & 3.970 & & 1.975 & & & & & 0.486 \\
\hline \multirow{6}{*}{ Normative belief } & NB1 & 3.790 & \multirow{6}{*}{3.141} & 2.260 & \multirow{6}{*}{2.044} & \multirow{6}{*}{0.818} & \multirow{6}{*}{0.834} & \multirow{6}{*}{0.488} & 0.358 \\
\hline & NB2 & 3.880 & & 2.092 & & & & & 0.398 \\
\hline & NB3 & 2.760 & & 1.944 & & & & & 0.500 \\
\hline & NB4 & 2.700 & & 1.986 & & & & & 0.944 \\
\hline & NB5 & 3.010 & & 1.936 & & & & & 0.818 \\
\hline & NB6 & 2.710 & & 2.048 & & & & & 0.911 \\
\hline \multirow{4}{*}{ Motivation to comply } & MTC1 & 4.970 & \multirow{4}{*}{3.950} & 1.993 & \multirow{4}{*}{1.977} & \multirow{4}{*}{0.779} & \multirow{4}{*}{0.787} & \multirow{4}{*}{0.487} & 0.663 \\
\hline & MTC2 & 3.820 & & 1.915 & & & & & 0.850 \\
\hline & MTC3 & 4.040 & & 2.128 & & & & & 0.517 \\
\hline & MTC4 & 2.970 & & 1.870 & & & & & 0.720 \\
\hline
\end{tabular}

Key: CR: Composite Reliability; AVE: Average variance extracted

Table 2: Accuracy analysis statistics

Source: Authors' own work

As indicated in the table above, all the items per construct had a mean that ranged from 3.141 to 5.730 . The standard deviation values ranged from 1.422 to 2.055. Furthermore, it was also observed that the standard deviation values were between -2 and +2 , indicating that data was fairly distributed. Reliability of the instrument was measured through Cronbach's alpha coefficients $(\alpha)$, reliability of all the dimension in the study was above the 0.7 threshold, indicating that the research instrument was reliable. Furthermore, composite reliability $(\mathrm{CR})$ values were also above 0.6 , further supporting the existence of reliability of the data. In order to test for validity of the data, the average variance extracted (AVE) values were used and these were above 0.5 , indicating validity of the data. Path modelling through structural equation modelling was performed to test the hypotheses proposed in the study. The results from the hypothesis testing are presented in table 3 and the figure below. 


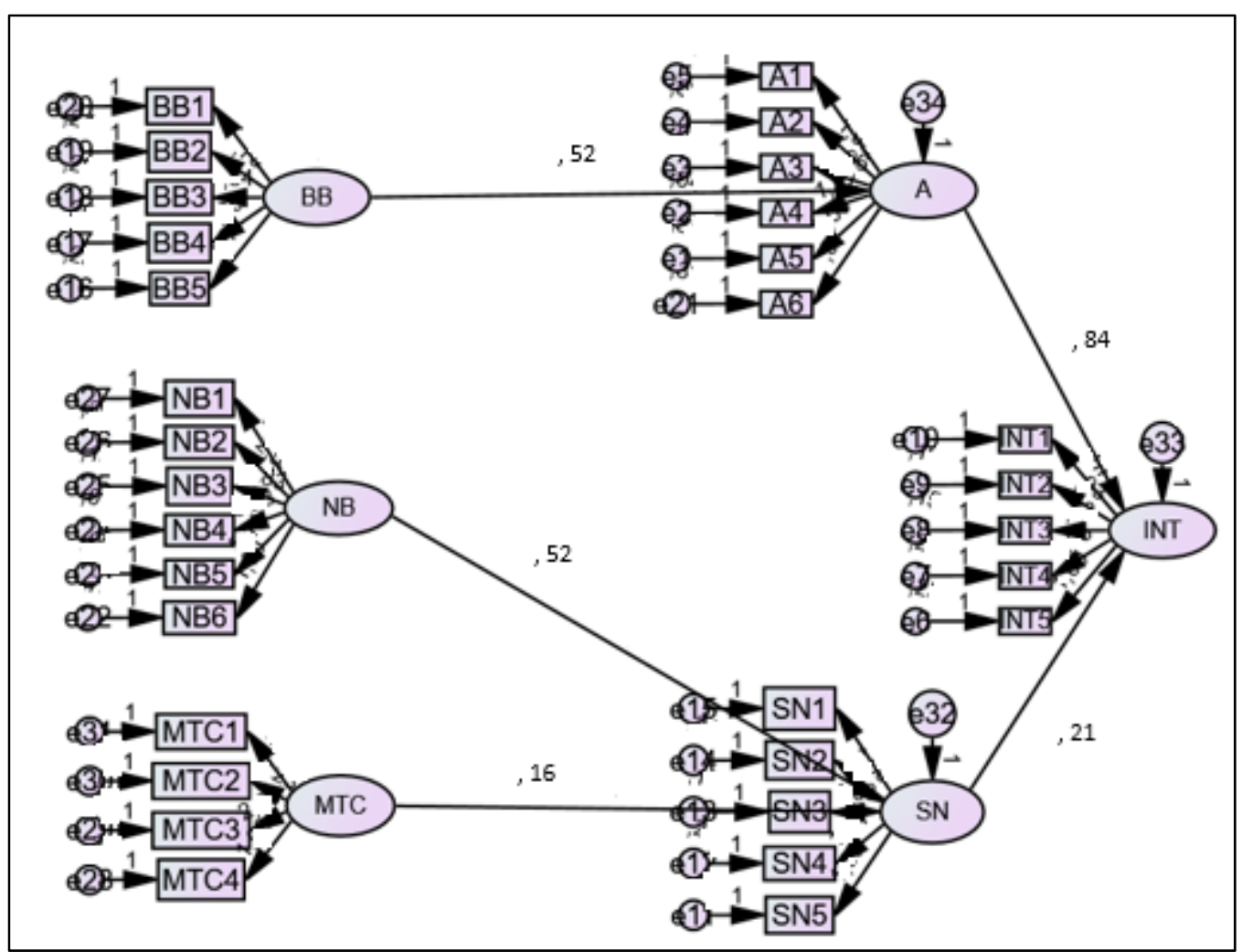

Key: BB: Behavioural beliefs, NB: Normative beliefs, MTC: Motivation to comply, A: Attitude, SN: Subjective Norm: INT: Intention to participate in religious festivals

Figure 2: Structural model

Source: Authors' own work

Figure 2 presents the outcomes form structural equation modelling of constructs from the proposed framework. The following section in table 3 illustrates the same results but also incorporates the impact observed from each of the relationships. For example, table 3 demonstrates whether a relationship was positive or negative. 


\begin{tabular}{|c|c|c|c|c|c|}
\hline \multicolumn{2}{|c|}{ Proposed hypothesis } & \multirow{2}{*}{$\begin{array}{c}\text { Path } \\
\text { coefficient } \\
0.84\end{array}$} & \multicolumn{2}{|c|}{ P-value \& Outcome } & \multirow{2}{*}{$\begin{array}{c}\text { Accepted/rejected } \\
\text { Accepted }\end{array}$} \\
\hline $\begin{array}{l}\text { Attitudes } \\
\rightarrow \text { intention }\end{array}$ & $\mathrm{H}_{1}$ & & *** & $\begin{array}{l}\text { Positive \& } \\
\text { Significant }\end{array}$ & \\
\hline $\begin{array}{l}\text { Subjective norm } \rightarrow \\
\text { intention }\end{array}$ & $\mathrm{H}_{2}$ & 0.21 & 0.006 & $\begin{array}{l}\text { Positive \& } \\
\text { Significant }\end{array}$ & Accepted \\
\hline $\begin{array}{l}\text { Behavioural belief } \\
\rightarrow \text { attitude }\end{array}$ & $\mathrm{H}_{3}$ & 0.52 & $* * *$ & $\begin{array}{l}\text { Positive \& } \\
\text { Significant }\end{array}$ & Accepted \\
\hline $\begin{array}{l}\text { Normative belief } \rightarrow \\
\text { subjective norm }\end{array}$ & $\mathrm{H}_{4}$ & 0.52 & 0.002 & $\begin{array}{l}\text { Positive \& } \\
\text { Significant }\end{array}$ & Accepted \\
\hline $\begin{array}{l}\text { Motivation to } \\
\text { comply } \rightarrow \\
\text { subjective norm }\end{array}$ & $\mathrm{H}_{5}$ & 0.16 & 0.065 & $\begin{array}{l}\text { Positive but } \\
\text { Not } \\
\text { significant }\end{array}$ & Rejected \\
\hline
\end{tabular}

\section{2) SUMMARY OF HYPOTHESES RESULTS}

All the proposed hypotheses were significant and supported at $p<0.01$ with the exception of the last hypothesis H5, which purports that motivation to comply has an impact on subjective norms ( $p$-value $=0.065)$. This hypothesis was therefore rejected. The first hypothesis which purports that attitudes have an impact on intention to participate was accepted. The hypothesis had a path coefficient of 0.84 which suggests that there was a positive and strong relationship between attitudes and intention to participate. In this vein, this finding implies that participants of religious festivals will have a strong intention to engage in religious festivals if they have positive attitudes towards the festivals. The second hypothesis, (subjective norms and intention), had a path coefficient of 0.21 which revealed that the subjective norms of an individual towards participating in religious festivals have a positive impact on their intention to participate in religious festivals. From this finding, it can be noted that the social pressure an individual experiences from relevant others influences their intention to participate in religious festivals. On the other hand, from the relationship that hypothesised the relationship between normative beliefs and subjective norms, it was found that normative beliefs have a positive 
impact on subjective norms. This posits that the beliefs that an individual holds in participating in a religious festival, have an impact on the influence of the social pressure that they receive from relevant others to participate in religious festivals. Furthermore, it was found in the study that motivation to comply has a positive impact on attitudes. This suggests that individuals who believe that it is important to participate in a religious festival will have positive attitudes towards the religious festivals. The following section explores the implications of the study. This is then followed by the conclusion of the study and recommendations for future studies.

\section{3) IMPLICATIONS OF THE FINDINGS}

The research led to the identification of numerous implications for both researchers and practitioners. Evidently, from the study, it can be argued that religious festivals organisers need to ensure that people's attitudes towards the festivals are positive. Conversely, retailers who stock and sell products that are targeted for specific religious festivals need to aid in creating positive attitudes towards the religious festivals. In this vein, marketing efforts, such as advertising the religious festivals in a favourable manner, could influence the attitudes of participants towards desiring to participate in the festivals. On the other hand, the influence of religious leaders towards encouraging individuals to participate in religious festivals is influenced by the individual's own personal beliefs and their motivation to comply. In this vein, religious leaders need to work towards moulding the beliefs of individuals about religious beliefs to ensure that these beliefs are positive. Thereafter, the positive influence of family members and friends in relation to participating in religious festivals can be realised once personal beliefs are favourable. Furthermore, based on the findings, it could be established that if people consider a festival to be important and relevant to them, their attitudes become positive towards that festival. This implies that event organisers should focus on framing religious festivals as paramount occasions to incentivise people to attend. In the same vein, findings posited that participants of religious festivals seek validation from their leaders so if event organisers win the hearts of the leaders in communities (religious leaders), they will by default, attract and secure the followers who would end up participating in the festival. In terms of implications for researchers, the study 
empirically tests a proposed theoretical framework which highlights the antecedents of the intention of individuals to participate in religious festivals. It can be noted that attitudes and subjective norms are theoretical constructs that positively impact people's intentions to participate in religious festivals.

\section{CONCLUSION}

This study was within the realm of religious tourism and sought to investigate the antecedents of the intentions to participate in religious festivals. The findings of the study showed that attitudes and subjective norms have a positive impact on the individual's intentions to participate in religious festivals. In this vein, if individuals believe that a religious festival is important, they can be positively influenced by relevant others to participate in the religious festival. However, an individual's motivation to comply does not have an impact on subjective norms. It can be noted that if an individual feels that a religious festival is important, their attitude towards the festival becomes positive which will positively influence their intention to participate in the religious festival. The results of this study are important in that they help explain the extent to which individuals are prepared and willing to attend religious festivals. This would therefore advise festival organisers and event managers on the motivation and needs of their audience.

\section{1) LIMITATIONS OF THE STUDY AND FURTHER RESEARCH}

The study, like any other, was not immune to restrictions. Limitations were twofold, first in research design, second theoretically. First, the research design did account for individuals' recency in attending religious festivals. In other words, the research design did allow the researchers to check how recently the participants had attended any religious festivals. Future researchers can check whether participants attended any religious festivals within the past year, six months, or one month. This would then classify research participants in a way that informs the readers on how useful or current their responses would be throughout the research. The research was also limited to volunteer participants in one city, Johannesburg. Since all participants were from one region, they might not have been the most scientific 
representation of people who engage in religious festivals. This could have created some sample bias since all these participants were exposed to the same environment in their daily lives and the same religious festivals. Future researchers could reduce this sample bias by considering a more diverse sample, possibly through an online survey. Theoretically, a limitation was that some potential hypotheses from the conceptual model were not tested, for example, the relationship between motivation to comply and attitudes toward engaging in religious festivals. Future research can also be in the form of qualitative research in which focus group discussions and interviews can be performed to ensure that a deep understanding of the intentions driving individuals to participate in religious festivals is explored. Future research can be longitudinal and not cross-sectional in nature. In this vein, the intentions of participants to participate in religious festivals at varying periods of the year can be explored. A comparative study of the intentions to participate in religious festivals can be performed between different religious groups.

\section{References}

Adiova, M.A. Music, Dance, and Negotiations of Identity in the Religious Festivals of Bicol, Philippines (Doctoral dissertation). Ann Arbor, Michigan: University of Michigan, 2014.

Ajzen, I. The theory of planned behavior. Organizational Behavior and Human Decision Processes, Vol. 50, No 2, 1991, pp. 179-211.

Ajzen, I. The theory of planned behaviour: reactions and reflections. Psychology \& Health, Vol. 26, No 9, 2011, pp 1113-1127.

Akman, I. Exploring adoption of social media commerce using extended theory of planned behaviour. International Conference on Economic, Education and Humanities (ICEEH14). Bali, Indonesia, 2014.

Albayrak, T.; Herstein, R.; Caber, M.; Drori, N.; Bideci, M.; Berger, R. Exploring religious tourist experiences in Jerusalem: The intersection of Abrahamic religions. Tourism Management, No 69, 2018, pp. 285-296. 
Amorim, D.; Jiménez-Caballero, J.L.; Almeida, P. Motivation and Tourists' loyalty In Performing Arts Festivals: The Mediator Role of Quality and Satisfaction. Enlightening Tourism. A Pathmaking Journal, Vol. 9, No 2, 2019, pp. 100-136.

Apleni, L.; Vallabh, D.; Henama, U.S. Motivation for tourists' participation in religious tourism in Eastern Cape: A case study of Buffalo City, South Africa. African Journal of Hospitality, Tourism and Leisure Studies, Vol. 6, No 2, 2017, pp. 1-14.

Bailey, J. M.; Sood, J. The effects of religious affiliation on consumer behavior: A preliminary investigation. Journal of Managerial Issues, Vol. 5, No 3, 1993, 328-352.

bin Haji Ishak, M.S.; Cultural and religious festivals: the Malaysian experience. JatiJournal of Southeast Asian Studies, No 15, 2010, pp. 97-111.

Celik, H.E.; Yilmaz, V. 'Extending the technology acceptance model for adoption of e-shopping consumers in Turkey', Journal of Electronic Commerce Research, Vol. 12, No 2, 2011, pp. 152-164.

Collins-Kreiner, N. Research pilgrimage: Continuity and transformation. Annals of Tourism Research, Vol. 37, No 2, 2010, pp. 440-456.

Cristea, A.A.; Apostol, M.S.; Dosescu, T. The role of media in promoting religious tourism in Romania. Procedia-Social and Behavioral Sciences, No 188, 2015, pp. 302-306.

Essoo, N.; Dibb, S. Religious influences on shopping behaviour: An exploratory study. Journal of Marketing Management, Vol. 20, No 7-8, 2004, pp. 683-712.

Fishbein, M.; Ajzen, I. Belief, Attitude, Intention, and Behavior: An Introduction to Theory and Research. Journal of Business Venturing, Vol. 5, 1975, pp. 177-189.

Gumpo, C.I.V.; Chuchu, T.; Maziriri, E.T.; Madinga, N.W. Examining the usage of Instagram as a source of Information for young consumers when determining tourist 
destinations. South African Journal of Information Management, Vol. 22, No 1, 2020, pp. 1-11.

Henama, U.S.; Sifolo, P.P.S. Religious Tourism in South Africa: Challenges, Prospects, and Opportunities. In: H. El-Gohary; D.J. Edwards; R. Eid (Eds.).Global Perspectives on Religious Tourism and Pilgrimage. New York: IGI Global, 2018, pp. 104-128.

Hilvert-Bruce, Z.; Neill, J.T. I'm just trolling: The role of normative beliefs in aggressive behaviour in online gaming. Computers in Human Behavior, No 102, 2020, pp. 303-311.

Jackowski, A.; Smith, V.L. Polish pilgrim-tourists. Annals of Tourism Research, Vol. 19, No 1, 1992, pp. 92-106.

Jiménez, E.U.; Martín, R.H. Analisis y tendencias del turismo [Analysis and trends of tourism]. Madrid: Pirámide, 2004.

Konietzny, J.; Caruana, A.; Cassar, M.L. Fun and fair, and I don't care: The role of enjoyment, fairness and subjective norms on online gambling intentions. Journal of Retailing and Consumer Services, Vol. 44, 2018, pp. 91-99.

Krogstad, K. Religious festivals in early childhood education and care (ECEC) institutions: A Norwegian case study. Nordisk Barnehageforskning, Vol. 16, No 3, 2017, pp. 1-15.

Lee, T.H.; Fu, C.J.; Chang, P.S. The support of attendees for tourism development: Evidence from religious festivals, Taiwan. Tourism Geographies, Vol. 17, No 2, 2015, pp. 223-243.

Leone, M. The Commercialization of Christmas in American Society. University of Florida, 2011. Available at: https://ufdc.ufl.edu/AA00060082/00001 [accessed 20 April 2020]. 
Lin, H.F. Applicability of the extended theory of planned behavior in predicting job seeker intentions to use job-search websites. International Journal of Selection and Assessment, Vol. 18, No 1, 2010, pp. 64-74.

Maziriri, E.T.; Mapuranga, M.; Madinga, N.W. Navigating selected perceived risk elements on investor trust and intention to invest in online trading platforms. Journal of Economic and Financial Sciences, Vol 12, No 1, 2019, pp 1-14.

Mhlophe, J.B. Antecedents of consumer purchase intentions towards organic food produces: A case study of the Johannesburg municipality (Master's thesis). Johannesburg: University of the Witwatersrand, 2015.

Nyaupane, G.P.; Timothy, D.J.; Poudel, S. Understanding tourists in religious destinations: A social distance perspective. Tourism Management, No 48, 2015, pp. 343-353.

Nyikana, S. Religious Tourism in South Africa: Preliminary analysis of a major festival in Limpopo. African Journal of Hospitality, Tourism and Leisure, Vol. 6, No 1, 2017, pp. 1-8.

Paul, A.A. Religious tourism-local economic development nexus. Euro Economica, Vol. 1, No 3, 2018, pp. 7-20.

Raykov, T. Evaluation of Convergent and Discriminant Validity with MultitraitMultimethod. British Journal of Mathematical and Statistical Psychology, Vol 64, No 1, 2011, pp. 38-52.

Rinschede, G. Forms of religious tourism. Annals of Tourism Research, Vol. 19, No 1, 1992, pp. 51-67.

Roberts-Lombard, M.; Parumasur, S.B. Consumer behaviour. Cape Town: Juta, 2017. 
Ron, A. Towards a typological model of contemporary Christian travel. Journal of Heritage Tourism, Vol. 4, No 4, 2009, pp. 287-297.

Sharpley, R.; Sundaram, P. Tourism: A sacred journey? The case of ashram tourism, India. International Journal of Tourism Research, Vol. 7, No 3, 2005, pp. 161-171.

Strydom, W. Applying the theory of planned behavior to recycling behavior in South Africa. Recycling, Vol. 3, No 3, 2018, pp. 1-20.

Suntikul, W.; Dorji, U. Local perspectives on the impact of tourism on religious festivals in Bhutan. Asia Pacific Journal of Tourism Research, Vol. 21, No 7, 2016, pp. 741-762.

Terzidou, M.; Scarles, C.; Saunders, M.N. The complexities of religious tourism motivations: Sacred places, vows and visions. Annals of Tourism Research, No 70, 2018, pp. 54-65.

Timothy, D.; Olsen, D. Tourism, religion and spiritual journeys. London: Routledge, 2006.

van Vuuren, C.; Slabbert, E. Travel behaviour of tourists to a South African holiday resort. African Journal for Physical, Health Education, Recreation and Dance, Vol. 17, No 4, 2011, pp. 694-70.

Wan, C.; Shen, G.Q.; Choi, S. The moderating effect of subjective norm in predicting intention to use urban green spaces: A study of Hong Kong. Sustainable Cities and Society, No, 37, 2018, pp. 288-297.

Weaver, P.A.; McCleary, K.W.; Han, J.; Blosser, P.E. Identifying leisure travel market segments based on preference for novelty. Journal of Travel \& Tourism Marketing, Vol. 26, No (5-6), 2009, pp. 568-584. 
Zhou, T. Understanding online community user participation: A social influence perspective. Internet Research, Vol. 21, No 1, 2011, pp. 68-81.

Zoonen, W.; Verhoeven, J.W.H.; Elving, W.J.L. Understanding work related social media use: An extension of the theory of planned behaviour. International Journal of Management, Economics and Social Sciences, Vol. 3, No 4, 2014, pp. 164-183.

\section{Appendix}

\section{Questionnaire}

Select the relevant option by placing an "X"

Section A

\begin{tabular}{|l|l|}
\hline Gender: & \\
\hline Male & \\
\hline Female & \\
\hline Prefer not to say & \\
\hline Age & \\
\hline $18-24$ & \\
\hline $25-34$ & \\
\hline $35-44$ & \\
\hline $45-54$ & \\
\hline $55-64$ & \\
\hline $65+$ & \\
\hline Education level & \\
\hline Diploma & \\
\hline Undergraduate & \\
\hline Postgraduate & \\
\hline Other & \\
\hline
\end{tabular}

What is your religion? (Optional)

\section{Section B}

*Please rate the following statements based on your understanding of what celebrating Christmas and Holi is?

\begin{tabular}{|l|l|l|l|l|l|l|l|l|l|}
\hline 1. I think celebrating Christmas is & Bad & 1 & 2 & 3 & 4 & 5 & 6 & 7 & Good \\
\hline 2. I think celebrating Christmas is & Unnecessary & 1 & 2 & 3 & 4 & 5 & 6 & 7 & Necessary \\
\hline 3. I think celebrating Christmas is & Boring & 1 & 2 & 3 & 4 & 5 & 6 & 7 & Fun \\
\hline 4. I think celebrating Holi is & Unpleasant & 1 & 2 & 3 & 4 & 5 & 6 & 7 & Pleasant \\
\hline 5. I think celebrating Holi is & Worthless & 1 & 2 & 3 & 4 & 5 & 6 & 7 & Valuable \\
\hline 6. I think celebrating Holi is & Boring & 1 & 2 & 3 & 4 & 5 & 6 & 7 & Fun \\
\hline
\end{tabular}

7. My family thinks I should celebrate Christmas/Holi

\begin{tabular}{|l|l|l|l|l|l|l|l|l|} 
Disagree & 1 & 2 & 3 & 4 & 5 & 6 & 7 & Agree \\
\hline
\end{tabular}




\begin{tabular}{|l|l|l|l|l|l|l|l|l|l|}
\hline $\begin{array}{l}\text { 8. My friends think I should celebrate } \\
\text { Christmas/Holi }\end{array}$ & Disagree & 1 & 2 & 3 & 4 & 5 & 6 & 7 & Agree \\
\hline $\begin{array}{l}\text { 9. My religious leader thinks I should celebrate } \\
\text { Christmas/Holi }\end{array}$ & Disagree & 1 & 2 & 3 & 4 & 5 & 6 & 7 & Agree \\
\hline $\begin{array}{l}\text { 10. My colleagues think I should celebrate } \\
\text { Christmas/Holi }\end{array}$ & Disagree & 1 & 2 & 3 & 4 & 5 & 6 & 7 & Agree \\
\hline $\begin{array}{l}\text { 11. My partner/spouse thinks I should } \\
\text { celebrate Christmas/Holi }\end{array}$ & Disagree & 1 & 2 & 3 & 4 & 5 & 6 & 7 & Agree \\
\hline $\begin{array}{l}\text { 12. I feel pressure from society to celebrate } \\
\text { Christmas/Holi }\end{array}$ & Disagree & 1 & 2 & 3 & 4 & 5 & 6 & 7 & Agree \\
\hline
\end{tabular}

\begin{tabular}{|l|l|l|l|l|l|l|l|l|l|}
\hline 13. I intend to buy gifts at Christmas & Disagree & 1 & 2 & 3 & 4 & 5 & 6 & 7 & Agree \\
\hline 14. I will definitely buy gifts at Christmas & Disagree & 1 & 2 & 3 & 4 & 5 & 6 & 7 & Agree \\
\hline 15. I want to buy gifts at Christmas & Disagree & 1 & 2 & 3 & 4 & 5 & 6 & 7 & Agree \\
\hline 16. I intend to participate in the Holi festival & Disagree & 1 & 2 & 3 & 4 & 5 & 6 & 7 & Agree \\
\hline $\begin{array}{l}\text { 17. I will definitely participate in the Holi } \\
\text { festival }\end{array}$ & Disagree & 1 & 2 & 3 & 4 & 5 & 6 & 7 & Agree \\
\hline 18. I want to participate in the Holi festival & Disagree & 1 & 2 & 3 & 4 & 5 & 6 & 7 & Agree \\
\hline
\end{tabular}

\begin{tabular}{|l|l|l|l|l|l|l|l|l|l|}
\hline $\begin{array}{l}\text { 19. Buying gifts at Christmas will make myself } \\
\text { and my family happy }\end{array}$ & Disagree & 1 & 2 & 3 & 4 & 5 & 6 & 7 & Agree \\
\hline $\begin{array}{l}\text { 20. In order to enjoy Christmas Santa Claus } \\
\text { must be a part of it }\end{array}$ & Disagree & 1 & 2 & 3 & 4 & 5 & 6 & 7 & Agree \\
\hline $\begin{array}{l}\text { 21. I will spend more time at a mall/store if it is } \\
\text { elaborately decorated }\end{array}$ & Disagree & 1 & 2 & 3 & 4 & 5 & 6 & 7 & Agree \\
\hline $\begin{array}{l}\text { 22. In order to celebrate Holi I must participate } \\
\text { in this festival }\end{array}$ & Disagree & 1 & 2 & 3 & 4 & 5 & 6 & 7 & Agree \\
\hline $\begin{array}{l}\text { 23. In order to celebrate Holi I must throw } \\
\text { coloured powder at other people }\end{array}$ & Disagree & 1 & 2 & 3 & 4 & 5 & 6 & 7 & Agree \\
\hline
\end{tabular}

\begin{tabular}{|l|l|l|l|l|l|l|l|l|l|}
\hline 24. My parents would expect me to buy gifts & Unlikely & 1 & 2 & 3 & 4 & 5 & 6 & 7 & Likely \\
\hline 25. My friends would expect me to buy gifts & Unlikely & 1 & 2 & 3 & 4 & 5 & 6 & 7 & Likely \\
\hline $\begin{array}{l}\text { 26. My religious leader would expect me to } \\
\text { buy gifts }\end{array}$ & Unlikely & 1 & 2 & 3 & 4 & 5 & 6 & 7 & Likely \\
\hline $\begin{array}{l}\text { 27. My parents would expect me to attend the } \\
\text { Holi Festival }\end{array}$ & Unlikely & 1 & 2 & 3 & 4 & 5 & 6 & 7 & Likely \\
\hline $\begin{array}{l}\text { 28. My friends would expect me to attend the } \\
\text { Holi festival }\end{array}$ & Unlikely & 1 & 2 & 3 & 4 & 5 & 6 & 7 & Likely \\
\hline $\begin{array}{l}\text { 29. My religious leader would expect me to } \\
\text { attend the Holi festival }\end{array}$ & Unlikely & 1 & 2 & 3 & 4 & 5 & 6 & 7 & Likely \\
\hline
\end{tabular}

\begin{tabular}{|l|l|l|l|l|l|l|l|l|l|}
\hline $\begin{array}{l}\text { 30. Generally speaking how much do you care } \\
\text { what your family thinks you should do }\end{array}$ & Not at all & 1 & 2 & 3 & 4 & 5 & 6 & 7 & $\begin{array}{l}\text { Very } \\
\text { much }\end{array}$ \\
\hline $\begin{array}{l}\text { 31. Generally speaking how much do you care } \\
\text { what your friends thinks you should do }\end{array}$ & Not at all & 1 & 2 & 3 & 4 & 5 & 6 & 7 & $\begin{array}{l}\text { Very } \\
\text { much }\end{array}$ \\
\hline $\begin{array}{l}\text { 32. Generally speaking how much do you care } \\
\text { what your religious leader thinks you should } \\
\text { do }\end{array}$ & Not at all & 1 & 2 & 3 & 4 & 5 & 6 & 7 & $\begin{array}{l}\text { Very } \\
\text { much }\end{array}$ \\
\hline $\begin{array}{l}\text { 33. Generally speaking how much do you care } \\
\text { what society thinks you should do }\end{array}$ & Not at all & 1 & 2 & 3 & 4 & 5 & 6 & 7 & $\begin{array}{l}\text { Very } \\
\text { much }\end{array}$ \\
\hline
\end{tabular}


Thank you for your time and patience.

Article info: Received 16/12/2019. Accepted 20/04/2020. Refereed anonymously. 